\title{
Understanding gender, marital status \& education as internal migration factors in developing countries
}

\author{
Dibyo Waskito Guntoro*, Setyabudi Indartono*, Irmadatus Sholekhah* \\ *Magister Economic Education, Graduate School Universitas Negeri Yogyakarta
}

\begin{tabular}{l}
\hline \hline INFO ARTIKEL \\
\hline Riwayat Artikel: \\
Dikirim: $21-2-2019$ \\
Disetujui: $17-5-2019$ \\
Diterbitkan: $30-6-2019$ \\
\hline
\end{tabular}

\section{Kata kunci:}

Internal Migration; Gender; Marital Status; Education

\section{Alamat Korespondensi:}

Dibyo Waskito Guntoro

Magister Economic Education

Graduate School, Universitas Negeri Yogyakarta

Kampus Karangmalang, Yogyakarta 55281

E-mail: dibyowaskitoguntoro.2017@student.uny.ac.id

\section{INTRODUCTION}

Control of the number and quality of the main human resources are the main priority in developing countries. According to (Putranto \& Kusuma, 2009) socio-economic
Abstract: This study aims to understand the factors of gender, marital status, and education in influencing the decision to carry out internal migration in developing countries, especially Indonesia between 2007-2015. This study uses secondary data in 2007 and 2015 from the Indonesian Family Life Survey (IFLS). After cleaning and adjusting data, a total of 4,642 respondents who met the requirements were used as research samples. The results showed that individual characteristics of sex and marital status had a significant effect on the tendency for internal migration in Indonesia. as well as the migration. Further research requires a deeper review of social and economic fac-

Abstrak: Penelitian ini bertujuan untuk memahami faktor gender, status perkawinan, dan pendidikan dalam mempengaruhi keputusan melakukan migrasi internal di negara berkembang, khususnya Indonesia antara tahun 20072015. Penelitian ini menggunakan data sekunder tahun 2007 dan 2015 dari Indonesian Family Life Survey (IFLS). Setelah dilakukan pembersihan dan penyesuaian data, sebanyak 4.642 responden yang memenuhi syarat dijadikan sebagai sampel penelitian. Hasil penelitian menunjukkan bahwa faktor karakteristik individu yang terdiri dari jenis kelamin dan status perkawinan berpengaruh signifikan terhadap kecenderungan melakukan migrasi internal di Indonesia. Begitu juga pendidikan menentukan seseorang melakukan migrasi. Penelitian selanjutnya diperlukan tinjauan lebih dalam mengenai faktor sosial dan ekonomi.

This is an open access article under the CC-BY-SA license.

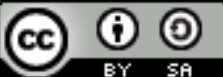


Jurnal Pendidikan Geografi:

Kajian, Teori, dan Praktik dalam Bidang Pendidikan dan Ilmu Geografi

Tahun 24, Nomor 2, Jun 2019, Hal 98-107

development in developing countries has a distinctive obstacle factor, namely a fairly high level of population growth. The expected population growth rate in the quotation describes the number of population increases which increases every year. According to Mantra (1985), the population growth rate is based on three factors, namely fertility (mortality), mortality (death) and population mobilization.

Inequality that occurs between one region and another causes people to be motivated or interested in moving from one region to another (Rustariyuni, 2013). Therefore, regional development needs to be directed to further develop and harmonize the rate of growth between regions, both urban areas and also regions (Wilonoyudho, 2009). The existence of population mobility from rural areas towards examples of the existence of differences in growth and inequality of regional development between regions (Listyarini \& Poerwono, 2011; Purnomo, 2009).

Some theories that stated about mobility in question are theories of need and stress (Adika, 2008; Mantra, 1985). Every individual has needs that must be discussed consisting of economic, social, political and psychological needs. If these needs are not met, stress will occur. Migration is an interest that satisfies and satisfies individuals and households to existing places (Santoso, 2010; Yuliarmi \& Riyasa, 2007). If the satisfaction of the new place is enough to deviate from the needs and expectations, then the individual will consider looking for a new location.

Meeting the needs of life must be completed. Until now migrants have made economic motives as a reason for someone to make a move. The majority of the population migrates for economic reasons (Gilbert \& Gugler, 1996; Pangaribuan \& Handayani, 2013; Suhaeni, 2010). There are also those caused by natural disasters (Dustmann \& Weiss, 2007; Susetyo, 2008). Economic factors needed can be in the form of employment status, wage level, total income, home ownership, and ownership of agricultural land. People urge to move to areas that are invited to live better (Pratiwi, 2012; Swasono \& Singarimbun, 1985).

The existence of relationship theory and current research is not appropriate. (Ravenstein, 1885) admired seven advocacy laws, but in the 6th and 7th laws it was not in accordance with some of the results of current research. Male hunting rates are higher compared to women (Santoso, 2010). More urban residents do circular transitions (Erlando \& Pratomo, 2013).

Traffickers usually occur during productive periods (Widodo, 2011). According to Sukamdi \& Mujahid (2015), many migrants make transitions at the age of 15-24 years, while non-migrants (people who do not make the transition) are in the age range of 35-44 years. As with Shaw's research, teenagers more migrate from groups that receive 20-29 years (Gilbert \& Gugler, 1996; White \& Naafs, 2012). Can be approved as a result of discussions conducted by young people.

Education in the regions both in rural and rural areas (Pangaribuan \& Handayani, 2013). There is a consistent pattern based on rural-urban migration studies, that there is a positive correlation between the level of education achieved and the tendency to migrate besides the personal drive to migrate (propensity to migrate) (Todaro, 1992). Someone has a higher education, with ceteris paribus having the possibility to migrate more. So that the pattern of urban village migration in Indonesia will still occur if the income gap, employment opportunities, and social facilities between regions diminish.

The problems of migration especially internally to date have not been accurately calculated such as fertility and mortality. This is due to technological developments and transportation, which causes mobility to be more flexible. For this reason, a continuous survey is needed to be able to see the mobility of migrants. The survey results are useful 
Jurnal Pendidikan Geografi:

Kajian, Teori, dan Praktik dalam Bidang Pendidikan dan Ilmu Geografi

Tahun 24, Nomor 2, Jun 2019, Hal 98-107

for finding out what factors cause a person to do an internal migration. This study aims to determine what factors cause a person to do an internal migration. This is useful to be a consideration for policy makers to be able to control or prepare their regions to receive or lose their citizens.

\section{METHODS}

The research data were sourced from the Indonesian Family Life Survey (IFLS) survey. The IFLS is a nationally representative sample consisting of households and individuals spread throughout the provinces of Java, Sumatra, Bali, Nusa Tenggara, Kalimantan and Sulawesi. IFLS has conducted five surveys, namely in 1993 (IFLS1), 1997 (IFLS2), 2000 (IFLS3), 2007 (IFLS4) and 2015 (IFLS5) with longitudinal respondents. In this study the respondents used were individuals who answered all questions in full in 2007 (IFLS 4) and 2015 (IFLS 5) on an ongoing basis. Data for each individual in the IFLS4 was 29,967 people and 36,391 people in the IFLS5 and found panel data of 24,255 individuals. Data cleaning is done by removing respondents under the age of 15 years and the main activities other than going to school. After cleaning and adjusting the data, 4,642 respondents were obtained as the research sample.

This research is a quantitative type using Probit Model analysis techniques (Ai \& Norton, 2003). The probit model is used to analyze the dependent variable which is categorical in two categories. The equation of the probit regression model used in this study is as follows:

$$
y=\alpha+\beta X 1+\beta X 2+\beta X 3+\beta X 4+\beta X 5+\beta X 6+\beta X 7+e
$$

Information:

$\mathrm{y}=$ The probability of the respondent migrating (1: if the respondent migrates, 0 : does not migrate)

$\mathrm{X} 1=$ Gender (1: Male, 0: Female)

$\mathrm{X} 2$ = Marital Status (1: Marriage, 0: Other)

X3 = Educational Respondents at High School Level (1: High School, 0: Other)

X4 = Vocational School Respondent Education (1: Vocational School, 0: Other)

X5 = Respondent's Higher Education (1: Diploma, Bachelor, UT, Master, Doctor, 0: Other)

X6 = Father's Higher Education (1: Diploma, Bachelor, UT, Master, Doctor, 0: Other)

X7 = Higher Education Mother (1: Diploma, Bachelor, UT, Master, Doctor, 0: Other)

$\alpha=$ constant

$\beta=$ Coefficient

$\mathrm{e}=$ Error

\section{RESULT AND DISCUSSION}

Internal migration is a resident who moves beyond the administrative boundaries of the village / kelurahan between 2007 and 2015. In general, this research unit is individual panels aged 15 years and over in 2007 to 2015 with status other than attending school in 2007. As many as 4,642 were respondents in this study. When viewed from migratory behavior, the respondents who migrated were $27.06 \%$ while $72.94 \%$ did not migrate. Complete data can be seen in Table 1.

Probit Model Analysis is used to determine the factors that influence the population to do internal migration in developing countries, especially Indonesia. The results of the analysis are presented in Table 2 .

The estimation results in Table 2 show that the seven independent variables used in this study, there are six significant variables and one variable that is not significant. The 
Jurnal Pendidikan Geografi:

Kajian, Teori, dan Praktik dalam Bidang Pendidikan dan Ilmu Geografi

Tahun 24, Nomor 2, Jun 2019, Hal 98-107

variables that were significant at the 1 percent significance level consisted of gender, marital status, vocational education level respondents, higher education respondents, high school level education respondents, and maternal higher education had a significance of less than 5 percent. While one variable that is not significant is father's higher education.

Table 1. Data of Respondents

\begin{tabular}{|c|c|c|c|c|c|c|c|c|c|}
\hline \multirow[b]{2}{*}{ Variable } & \multicolumn{3}{|c|}{ ALL } & \multicolumn{3}{|c|}{ Migration } & \multicolumn{3}{|c|}{ Non Migration } \\
\hline & Obs & Mean & $\begin{array}{l}\text { Std. } \\
\text { Dev }\end{array}$ & Obs & Mean & $\begin{array}{l}\text { Std. } \\
\text { Dev }\end{array}$ & Obs & Mean & $\begin{array}{l}\text { Std. } \\
\text { Dev }\end{array}$ \\
\hline \multirow{2}{*}{ Migration } & 464 & .270573 & .444303 & 125 & & & 338 & & \\
\hline & 2 & & 7 & 6 & & & 6 & & \\
\hline \multirow[t]{2}{*}{ Gender } & 464 & .622145 & .484903 & 125 & .644904 & .478732 & 338 & .613703 & .486971 \\
\hline & 2 & 6 & 2 & 6 & 5 & 9 & 6 & 5 & 8 \\
\hline \multirow[t]{2}{*}{ Marital Status } & 464 & .880224 & .324734 & 125 & .728503 & .444908 & 338 & .936503 & .243890 \\
\hline & 2 & & 3 & 6 & 2 & 9 & 6 & 2 & 3 \\
\hline \multirow{2}{*}{$\begin{array}{l}\text { Senior High School Re- } \\
\text { spondents }\end{array}$} & 464 & .211546 & .408449 & 125 & .25 & .433185 & 338 & .197282 & .398006 \\
\hline & 2 & 7 & 1 & 6 & & 2 & 6 & 9 & 5 \\
\hline Vocational High School & 464 & .159198 & .365900 & 125 & .212579 & .409295 & 338 & .139397 & .346412 \\
\hline Respondents & 2 & 6 & 6 & 6 & 6 & 6 & 6 & 5 & \\
\hline \multirow{2}{*}{$\begin{array}{l}\text { Respondents Higher Educa- } \\
\text { tion }\end{array}$} & 464 & .194097 & .395546 & 125 & .218152 & .413156 & 338 & .185174 & .388496 \\
\hline & 2 & 4 & 8 & 6 & 9 & 3 & 6 & 2 & 2 \\
\hline \multirow[t]{2}{*}{ Father's Higher Education } & 464 & .027358 & .163144 & 125 & .042993 & .202923 & 338 & .021559 & .145261 \\
\hline & 2 & 9 & 5 & 6 & 6 & 5 & 6 & 4 & 1 \\
\hline \multirow[t]{2}{*}{ Mother's Higher Education } & 464 & .013787 & .116619 & 125 & .026273 & .160012 & 338 & .009155 & .095258 \\
\hline & 2 & 2 & 1 & 6 & 9 & 4 & 6 & 3 & 6 \\
\hline
\end{tabular}

The next stage after knowing the independent variables on variables that are expected to know marginal effects. Marginal effect is the change in value of each independent variable on the received variable. Presented are presented in Table 2.

Table 2. Results of Probit Model Estimation

\begin{tabular}{cc}
\hline Variable & Coefficient \\
Gender & .1468107 \\
Marital Status & $(.0480346)^{* * *}$ \\
(1= Kawin) & -.8033238 \\
& $(.066057)^{* * *}$ \\
Senior High School Respondents (1 = Senior Hugh School) & .1482763 \\
& $(.0578911)^{* *}$ \\
Vocational High School Respondents & .2437491 \\
(1= Vocational High School) & $(.063268)^{* * *}$ \\
Respondents Higher Education & .1788898 \\
(1= Diploma, S1, UT,S2,S3,) & $(.0631526)^{* * *}$ \\
Father's Higher Education & .1088678 \\
(1= Diploma, S1, UT,S2,S3,) & $(.1294535)$ \\
Mother's Higher Education & .44015475 \\
(1= Diploma, S1, UT,S2,S3,) & $(.1797208)^{* *}$ \\
cons & 1.151229 \\
Log Likelihood & $(.1268589)$ \\
LR chi2(13) & -2236.8133 \\
Prob > Chi2 & 956.63 \\
Pseudo R2 & 0.0000 \\
\hline Source IFLS4 and & 0.1746 \\
\hline
\end{tabular}

Source: IFLS4 and IFLS5 data, processed

\section{Hypothesis Testing Results}

The results of testing the marginal effect of the influence of sex factors on the decision to carry out internal migration in Indonesia showed a probability coefficient of 
Jurnal Pendidikan Geografi:

Kajian, Teori, dan Praktik dalam Bidang Pendidikan dan Ilmu Geografi

Tahun 24, Nomor 2, Jun 2019, Hal 98-107

0.0450671 and had a positive direction. This condition means that partially the probability of men is 4.5 percent higher in migrating compared to women.

Table 3. Results of Marginal Effect Estimates

\begin{tabular}{cc}
\hline Variabel & Koefisien \\
Gender & .0450671 \\
Marital Status & $(.01454)^{* * *}$ \\
$(1=$ Married $)$ & -.2892903 \\
& $(.02561)^{* * *}$ \\
Senior High School Respondents (1 = Senior High School) & .0474686 \\
& $(.01903)^{* *}$ \\
Vocational High School Respondents & .0799994 \\
$(1=$ Vocational High School) & $(.02176)^{* * *}$ \\
Respondents Higher Education & .0577056 \\
(1= Diploma, S1, UT,S2,S3, $)$ & $(.02105)^{* * *}$ \\
Father's Higher Education & .0350604 \\
(1= Diploma, S1, UT,S2,S3, $)$ & $(.04307)$ \\
Mother's Higher Education & .1399491 \\
$(1=$ Diploma, S1, UT,S2,S3, $)$ & $(.06819)^{* *}$ \\
\hline
\end{tabular}

Source: IFLS4 and IFLS5 data, processed

Testing the effect of marital status factors on the decision to carry out internal migration in Indonesia shows a probability coefficient of -0.2892903 . This means that partially the respondents with married status have a probability of migrating 28.9 percent lower than respondents with a status other than marriage.

The test results of the influence of the education factors of high school level respondents on the decision to carry out internal migration in Indonesia obtained a coefficient of 0.0474686 in a positive direction. These results indicate that respondents who have a high school education background have a 4.7 percent greater probability of migrating compared to respondents not from high school education.

Testing the marginal effect of the influence of the education factors of the vocational level respondents on the decision to carry out internal migration in Indonesia obtained a coefficient of 0.0799994 in a positive direction. These results indicate that respondents who have a vocational education background have a greater probability of migrating 7.9 percent compared to respondents not having a vocational education.

Testing the effect of respondents' higher education factors on the decision to make internal migration in Indonesia obtained a coefficient of 0.0577056 in a positive direction. These results indicate that respondents who have a higher education background have a greater probability of migrating 5.7 percent compared to respondents who are not highly educated.

Testing the marginal effect of the influence of the father's higher education factor on the decision to carry out internal migration in Indonesia obtained a probability coefficient of 0.0350604 . These results indicate that father's higher education does not affect the decision making of internal migration in Indonesia.

Testing the effect of maternal higher education factors on the decision to make internal migration in Indonesia shows the probability coefficient value of 0.1399491 in a positive direction. These results indicate that respondents whose mothers with higher education backgrounds have a greater probability of migrating 13.9 percent compared to respondents who have mothers with other educational backgrounds.

After knowing the effect of independent variable factors on the dependent variable partially, then looking at the effect of independent variables on the dependent variable simultaneously. Knowing the effect simultaneously can be known through the following criteria: Prob> x $2=0.00000$. 
Jurnal Pendidikan Geografi:

Kajian, Teori, dan Praktik dalam Bidang Pendidikan dan Ilmu Geografi

Tahun 24, Nomor 2, Jun 2019, Hal 98-107

The results in table 2 show that the value of Chi Square shows 0,000 means a significance value of $<5 \%$. So it can be concluded that simultaneously, the factors of individual characteristics (gender and marital status) and socioeconomic status factors (respondent's education, father's higher education, and maternal higher education) together influence the decision of internal migration in Indonesia.

\section{Discussion}

\section{Characteristics of Individuals Affecting the Decision to Conduct Internal Migration in Indonesia}

Individual characteristic factors consisting of gender and marital status variables influence the decision to carry out internal migration in Indonesia. The results of the descriptive analysis show that there are more men who migrate compared to women. Based on the analysis of sex probit models, it has a positive and significant effect on the decision to carry out internal migration in Indonesia.

The sex factor in this study is not in accordance with Ravenstein's law which states that more women migrate compared to men (Ravenstein, 1885). This different result can be caused because Ravenstein's law no longer fits the current conditions. Because this law appeared in the 1880s. At present, there are more migrant male migrants than women. The proportion of male sex is greater than women in migrating (Santoso, 2010; Wajdi, 2010).

Based on the results of statistical calculations, more respondents with married status migrated. The results of the calculation of the probit model indicate that marital status has a negative and significant effect on the decision to carry out internal migration in Indonesia. This means that respondents who are married have a lower probability of migrating compared to other statuses. The phenomenon of migrating in developing countries is because the decision to migrate is at the individual level, meaning that those who have not married will tend to be freer because there are no dependents and responsibilities only to themselves, so they will have a greater chance of migrating. (Todaro, 1992).

Marital status factors are related to the cost of migrating. Before migrants decide to migrate there will be a lot of costs to be incurred, such as transportation costs, meals, the cost of buying new assets in the destination, and lodging (Campbell, Brue, \& Macpherson, 1995). If the migrants are not married, the costs incurred are not too large, whereas if they are married and have children, the costs incurred are even greater.

Supporting the results of internal migration in Pakistan, shows that male migrants with married status have a negative and significant influence, while married female migrants have a positive and significant influence (Nisar, Akram, \& Hussain, 2013). This means that more men are migrating when they are not married yet. On the contrary, more women make transfers after being married. Married women have a high level of mobility on the grounds that they follow their husbands.

Marital status can affect the decision to migrate when viewed from the destination of migration (Purnomo, 2009). More migrants heading to Java are currently married, compared to migrants who migrate to Java, especially DKI Jakarta. This happened because there were many transmigrants from Java to Sumatra who already had families. The presence of relatives in the destination area makes the costs incurred not too large because it can be shared in the location of the transmigrants. If there are one hundred migrants with marriages, then those going to DKI Jakarta will amount to 34 people, while among one hundred unmarried people, those who go to DKI Jakarta number more than 38 people.

The individual characteristic factor in this study is that there is a greater proportion of the population who migrate to male population at the age of 15 and 25 years, and not 
Jurnal Pendidikan Geografi:

Kajian, Teori, dan Praktik dalam Bidang Pendidikan dan Ilmu Geografi

Tahun 24, Nomor 2, Jun 2019, Hal 98-107

married (Todaro, 1992). But descriptively the age of respondents who migrated in this study was more at the age of 27 years.

Socio-Economic Status Factors Affecting the Decision to Conduct Internal Migration in Indonesia.

\section{Respondent High School, Vocational, and Higher Education Education}

Education of respondents at the high school, vocational and high school levels has a positive and significant effect on the decision to carry out internal migration in Indonesia. The results of the analysis showed that the education of respondents at the high school, vocational and high school levels had a positive direction of 4.7 percent, 7.9 percent and 5.7 percent. It can be interpreted that respondents who have an educational background at the high school level have a 4.7 percent greater probability of migrating compared to respondents who are not high school educators. Similarly, respondents who have an educational background at the level of Vocational and Higher Education have a higher probability of migrating 7.9 percent and 5.7 percent compared to respondents who are not educated in Vocational and Higher Education. Among the three levels of education, education with vocational level has a greater influence of 7.9 percent.

The last level of education has a positive and significant effect on the interest in labor migrating (Rahmawati \& Wiratno, 2010). Someone will make a move if they are relatively young, have higher education, get married, are healthy and have financial stability (Park \& Kim, 2015). That there is a positive correlation between the level of education and migration. A clear relationship between the level of education achieved and the tendency to mitigate is for someone who is taking longer education (Todaro, 1992). Besides that the education factor can also be linked to the modern theory of migrant internal migration as consumers (Bodvarsson \& Van den Berg, 2009). The intended consumption is the existence of amenesties, especially public goods in the form of schools or educational institutions. So that the decision to carry out internal migration in Indonesia is not only due to the driving factors of the level of education being completed, but the reason for migrating can be due to better education.

\section{Parent Higher Education}

The results of the analysis show that father's education has no significant effect on the decision to carry out internal migration in Indonesia. Because the results of the probit model have an error rate greater than the significance level of 5\%. As with the mother's education, it has a positive and significant effect on the decision to carry out internal migration in Indonesia. Respondents who have mothers with a higher education background have a greater probability of migrating 13.9 percent compared to respondents who have mothers with other education.

A mother who has high knowledge and education will find it easier to provide solutions to household problems. Likewise, in making decisions about internal migration in Indonesia. The role of parents in this case is a mother's greater influence in giving more attention to the future of her child. Migration decisions can be determined by altruistic factors of parents towards children (Fitri, 2018). Altruism can be interpreted as the nature of wanting to please or pay attention to the interests of others. The greater the altruistic factor of parents towards children, the greater the chance to migrate even though by looking at the consideration of the costs incurred and the benefits to be received.

Altruistic roles of parents should not be separated from the attention of father and mother. However, in the context of the results of this study. Father's educational background does not significantly influence the decision to carry out internal migration in Indonesia. It is inversely proportional to the education status of mothers who have a 
Jurnal Pendidikan Geografi:

Kajian, Teori, dan Praktik dalam Bidang Pendidikan dan Ilmu Geografi

Tahun 24, Nomor 2, Jun 2019, Hal 98-107

positive and significant influence. This means that the role of the mother in giving greater attention to her child. So that a greater altruistic role is given by mothers than fathers.

\section{CONCLUSION}

The results of the analysis of this study indicate that individual characteristic factors consisting of sex variables and marital status significantly influence the decision to make internal migration in Indonesia. Based on the results of probit regression and marginal effect male sex has a positive direction. Partially the probability of men is 4.5 percent higher than for women. Marital status has a negative direction of -0.79 percent and -28.9 percent. Can be interpreted if someone is married then the probability of migrating is 28.9 percent lower than the status other than marriage.

The factors of socio-economic status consisted of the education dummy variables of high school respondents, the education dummy of respondents at the vocational level, the respondent's high education dummy, the father's dummy education variable, and the mother's dummy education variable. The respondent's dummy education variable, maternal higher education significantly influences the decision to carry out internal migration in Indonesia, while father's higher education does not significantly influence the decision to carry out internal migration in Indonesia. The education dummy variables of the respondents at the high school, vocational, and tertiary levels have a positive direction of 4.7 percent, 7.9 percent and 5.7 percent. This means that the respondents who migrated with high school, vocational, and tertiary education had the probability of conducting internal migration sequentially 4.7 percent, 7.9 percent, and 5.7 percent greater than respondents other than high school, vocational education. and higher education. Similarly, maternal higher education has a positive direction of 14 percent. This means that respondents who have mothers with higher education have a probability of conducting internal migration by 14 percent greater than respondents who have mothers other than higher education.

This study has several limitations which include internal spaces that only cross the boundaries of the village / "kelurahan" so that they cannot make patterns of movement between provinces and islands. There are no boundaries, no destination boundaries, so the village /'kelurahan" boundaries as well as crossing provincial and island boundaries are also the limitations of research. Further research needs to make changes to variables that improve internal distribution, age, place of residence, number of family members, social status, and regional income to be able to see the difference in income. Further research must reveal internal influencing factors that occur in developing countries other than in Indonesia, see also in other countries.

\section{REFERENCES}

Adika, I. N. (2008). Pengembangan wilayah kabupaten Sidoarjo sebagai wilayah pinggiran kota metropolitan Surabaya dan mobilitas penduduk. Piramida, 4(1), 1-19.

Ai, C., \& Norton, E. C. (2003). Interaction terms in logit and probit models. Economics Letters, 80(1), 123-129.

Bodvarsson, Ö. B., \& Van den Berg, H. (2009). Immigration policy in the United States. In The Economics of Immigration (pp. 349-377). Springer.

Campbell, R. M., Brue, S. L., \& Macpherson, D. A. (1995). Contemporary labour economics. Singapore: McGraw-Hill, Inc.

Dustmann, C., \& Weiss, Y. (2007). Return migration: theory and empirical evidence from the UK. British Journal of Industrial Relations, 45(2), 236-256.

Erlando, A., \& Pratomo, D. S. (2013). Analisis terhadap migran sirkuler di kota Surabaya. 
Jurnal Pendidikan Geografi:

Kajian, Teori, dan Praktik dalam Bidang Pendidikan dan Ilmu Geografi

Tahun 24, Nomor 2, Jun 2019, Hal 98-107

Jurnal Ilmiah Mahasiswa FEB, 2(1).

Fitri, K. S. (2018). Analisis migrasi internal tenaga kerja Indonesia tahun 2007-2014. Retrieved from http://repository.unej.ac.id/handle/123456789/88834

Gilbert, A., \& Gugler, J. (1996). Urbanisasi dan kemiskinan di dunia ketiga. Yogyakarta: Tiara Wacana Yogya.

Listyarini, N., \& Poerwono, D. (2011). Faktor-faktor individual yang mempengaruhi minat migrasi tenaga kerja wanita kabupaten Pati Jawa Tengah ke Malaysia (studi kasus: kecamatan Sukolilo kecamatan Gabus dan kecamatan Tayu). Universitas Diponegoro.

Mantra, I. B. (1985). Pengantar studi demografi. Yogyakarta: Nur Cahaya.

Nisar, A., Akram, A., \& Hussain, H. (2013). Determinants of internal migration in Pakistan. The Journal of Commerce, 5(3), 32.

Pangaribuan, K. H., \& Handayani, H. R. (2013). Analisis pengaruh pendapatan, pendidikan, pekerjaan daerah asal, jumlah tanggungan, dan status perkawinan terhadap keputusan migrasi sirkuler ke kota Semarang (studi kasus: kec. Tembalang dan kec. Pedurungan). Fakultas Ekonomika dan Bisnis.

Park, J., \& Kim, K. (2015). Internal migration of the elderly in Korea: a multilevel logit analysis of their migration decision. Asian and Pacific Migration Journal, 24(2), 187212.

Pratiwi, Q. (2012). Analisis migrasi penduduk ke kecamatan Simpang Kiri kota Subulussalam provinsi Aceh tahun 2005-2009. Univeritas Negeri Medan.

Purnomo, D. (2009). Fenomena migrasi tenaga kerja dan perannya bagi pembangunan daerah asal: studi empiris di kabupaten Wonogiri. Jurnal Ekonomi Pembangunan: Kajian Masalah Ekonomi Dan Pembangunan, 10(1), 84-102.

Putranto, T. T., \& Kusuma, K. I. (2009). Permasalahan airtanah pada daerah urban. Teknik, $30(1), 48-56$.

Rahmawati, T. M., \& Wiratno, W. (2010). Faktor yang mempengaruhi minat tenaga kerja untuk bekerja ke luar negeri (kasus: kota Semarang). Universitas Diponegoro.

Ravenstein, E. G. (1885). The laws of migration. Journal of the Statistical Society of London, 48(2), 167-235.

Rustariyuni, S. D. (2013). Faktor-faktor yang mempengaruhi minat migran melakukan mobilitas non permanen ke kota Denpasar. Piramida, 9(2).

Santoso, I. (2010). Faktor-faktor yang mempengaruhi keputusan bermigrasi penduduk Indonesia antara tahun 2000-2007 (analisis data ifls 2000 dan 2007). Jakarta: Universitas Indonesia.

Suhaeni, H. (2010). Tipologi kawasan perumahan dengan kepadatan penduduk tinggi dan penanganannya. Jurnal Permukiman, 5(3), 116-123.

Susetyo, H. (2008). Menuju paradigma keamanan komprehensif berperspektif keamanan manusia dalam kebijakan keamanan nasional Indonesia. Lex Jurnalica, 6(1).

Swasono, S.-E., \& Singarimbun, M. (1985). Sepuluh windhu transmigrasi di Indonesia, 1905-1985. Penerbit Universitas Indonesia.

Todaro, M. P. (1992). Pengembangan ekonomi di dunia 3. Kajian Migrasi Internal Di Negara Sedang Berkembang. Pusat Penelitian Kependudukan, UGM, Yogyakarta.

Wajdi, M. N. (2010). Migrasi antarpulau di Indonesia: analisis model skedul migrasi dan model gravitasi hybrida. Inter-Islands Migration in Indonesia: Model Migration Schedules and Hybrid Gravity Model Analysis]. Master's Thesis, University of Indonesia.

White, B., \& Naafs, S. (2012). Generasi antara: refleksi tentang studi pemuda Indonesia. Jurnal Studi Pemuda, 1(2), 89-106.

Widodo, S. (2011). Strategi nafkah berkelanjutan bagi rumah tangga miskin di daerah 
Jurnal Pendidikan Geografi:

Kajian, Teori, dan Praktik dalam Bidang Pendidikan dan Ilmu Geografi

Tahun 24, Nomor 2, Jun 2019, Hal 98-107

Pesisir. Hubs-Asia, 10(1).

Wilonoyudho, S. (2009). Kesenjangan dalam pembangunan kewilayahan. In Forum Geografi (Vol. 23, pp. 167-180).

Yuliarmi, N. N., \& Riyasa, P. (2007). Analisis faktor-faktor yang mempengaruhi kepuasan pelanggan terhadap pelayanan PDAM kota Denpasar. Buletin Studi Ekonomi, 12(1), 9-28. 